\title{
Wolność słowa - komunitariańska argumentacja uzasadniająca różnorodność znaczenia pojęcia
}

\begin{abstract}
Dostęp obywateli do informacji na temat spraw publicznych jest warunkiem wstępnym, koniecznym do tego, aby wspólnota polityczna nie dostała się pod kontrolę demagogów; aby podejmowano działania, gdy jest to potrzebne nam i innym; aby urzeczywistnione zostały zasady sprawiedliwości i możliwa była wspólna przyszłość ${ }^{1}$.
\end{abstract}

I. Wprowadzenie. Komunitaryzm, zwany również komunitarianizmem (communitarian, od ang. community - wspólnota) jest jednym ze stosunkowo młodych nurtów współczesnej filozofii politycznej². Autorów, zaliczanych jako przedstawicieli tego nurtu, takich jak: Alasdair MacIntyre ${ }^{3}$, Charles Taylor, Micheal Sandel, Michael Walzer czy Amitai Etzioni łączy dosyć jednorodne spojrzenie na tradycję, kulturę i społeczeństwo z punktu widzenia wartości wspólnotowych. Co istotne, komunitarianie nie oferują kompletnego programu politycznego, ani też żadnego sprecyzowanego projektu państwa, ponieważ zajmują się oni przede wszystkim opisem relacji społecznych ${ }^{4}$.

1 Komunitariańska platforma programowa. Społeczeństwo responsywne: prawa i obowiąki, [w:] Komunitarianie. Wybór tekstów, red. P. Śpiewak, Warszawa 2004, s. 25.

${ }^{2} \mathrm{~W}$ polskiej literaturze przedmiotu można spotkać się z dwojakim tłumaczeniem nazwy nurtu. Dominuje określenie „komunitaryzm”, z którego wynika, że jego przedstawicieli należy nazywać ,komunitarystami”. Niektórzy autorzy posługują się jednak zwrotami „komunitarianizm”, „komunitarianie”. W celu ujednolicenia nazewnictwa, na potrzeby niniejszego artykułu będę posługiwał się drugim z wymienionych zwrotów. Swój wybór uzasadniam pragnieniem odróżnienia przedstawicieli analizowanej myśli od podobnie brzmiących lecz zdecydowanie odległych intelektualnie i aksjologicznie reprezentantów „komunizmu”, czyli „komunistów”; szerzej na temat występowania obu zwrotów w polskiej literaturze naukowej: Ł. Dominiak, Wartość wspólnoty. O filozofii politycznej komunitaryzmu, Toruń 2010, s. 46

3 Pomimo tego, że sam MacIntyre sprzeciwił się, aby określano go mianem komunitarianina, por. A. MacIntyre, I'm not a Comunitarian, but..., ,The Responsive Community”, 1999 (Summer), t. I, nr 3, s. 91-92.

4 W polskiej literaturze przedmiotu analiza komunitarianizmu została znacząco zredukowana do płaszczyzny refleksji filozoficznej. Szerzej o komunitarianizmie politycznym: J. Grygieńć, 
Swoją wspólną orientację polityczną określają głównie przez opozycję wobec metodologicznego indywidualizmu cechującego współczesny liberalizm oraz libertarianizm, odnosząc się krytycznie w szczególności do dorobku naukowego Johna Rawlsa, Ronalda Dworkina oraz Roberta Nozicka 5 .

Celem niniejszego artykułu jest z jednej strony przedstawienie podstawowych założeń komunitarianizmu, z drugiej natomiast próba dokonania rekonstrukcji znaczenia terminu ,wolność słowa”, w oparciu o założenia metodologiczne analizowanej doktryny. W celu usystematyzowania wywodu najpierw przytoczę podstawowe poglądy komunitarian. Później omówię stanowisko Jeffrey'a Abramsona i Elizabeth Bussiere, zawarte w artykule Wolność słowa i prawo do swobodnego przekazu. Perspektywa Komunitariańska ${ }^{6}$. Pozwoli mi to sformułować w konkluzji odpowiedź na pytanie: czy według komunitarian można mówić o istnieniu jednej wspólnej definicji pojęcia wolności słowa, czy też nie byłoby właściwsze stwierdzenie, że mamy do czynienia $\mathrm{z}$ całym spektrum tych, różnych od siebie, wolności?

II. Podstawowe założenia komunitarianizmu. Pomimo wyznawania przez komunitarian podobnych poglądów i wartości, nie tworzą oni homogenicznej ideologii politycznej. Jedną z klasyfikacji omawianego nurtu przedstawił Andrzej Szahaj, wyróżniając komunitarianizm: liberalny (Michael Walzer), republikański (Charles Taylor), radykalny (Micheal Sandel) oraz nostalgiczny (Alasdair MacIntyre) ${ }^{7}$. Zupełnie inaczej ocenił poglądy przywołanych komunitarian Rafał Prostak, który napisał: „,Ton wypowiedzi Michaela Sandela przypomina obywatelski republikanizm, podczas gdy Charles Taylor brzmi miejscami jak organicystyczny konserwatysta. Z kolei Alasdair MacIntyre szczerze przyznaje się do inspiracji św. Tomaszem z Akwinu, co poniekąd tłumaczy jego arystotelizm, ale nie brak w jego argumentacji także elementów heglizmu i marksizmu. Natomiast Michael Walzer wielokrotnie ujawnia swoje socjalistyczne inklinacje"8. Na potrzeby niniejszego artykułu pominę jednak różnice występujące pomiędzy przedstawicielami analizowanej doktryny, skupiając się na przedstawieniu jedynie najważniejszych i wspólnych metodologicznie założeń, jakimi są: krytyka liberalnego indy-

W trosce o wspólnotę i demokrację. Henry Tam i komunitarystyczny projekt polityczny, [w:] H. Tam, Komunitaryzm. Nowy program polityczny i obywatelski, Torun 2011, s.7-36.

5 E. Frazer, the Problems of Communitarian Politics. Unity and Conflict, Oxford 2006, s. 15-20 .

6 J. Abramson, E. Bussiere, Wolność słowa i prawo do swobodnego przekazu. Perspektywa Komunitariańska [w:] Komunitarianie..., s. 373-388.

7 Szerzej: A. Szahaj, Jednostka czy wspólnota? Spór liberałów z komunitarystami a , sprawa polska”, Warszawa 2000.

${ }^{8}$ R. Prostak, Rzecz o sprawiedliwości. Komunitarystyczna krytyka współczesnego liberalizmu amerykańskiego, Kraków 2004, s. 96. 
widualizmu, wizja człowieka zakorzenionego we wspólnocie oraz koncepcja państwa9.

Krytyka liberalnego indywidualizmu. Komunitarianie, podobnie jak konserwatyści i republikanie, uważają, że afirmacja autonomii i samodzielności decyzyjnej jednostki oznacza jej społeczną alienację, spowodowaną wyrwaniem z naturalnego kontekstu wspólnotowego. Za sprawą tego wyobcowania samo społeczeństwo zaczyna być postrzegane jako zbiorowisko bezładnie krążących atomów ${ }^{10}$. Komunitarianizm stanowi zatem niezbędną współcześnie korektę liberalizmu, odnoszącą się przede wszystkim do niebezpieczeństwa wynikającego $\mathrm{z}$ aspołecznego indywidualizmu, atomizacji więzi społecznych, fragmentaryzacji życia zbiorowego oraz deprecjonowania wspólnoty ${ }^{11}$. Dlatego przedstawiciele omawianego nurtu ostrzegają przed rozbiciem wspólnot sąsiedzkich, lokalnych, stowarzyszeniowych, a nawet rodzinnych, winiąc za te procesy przywołany już wcześniej egoistyczny indywidualizm. O niebezpieczeństwie takich przemian pisał już wcześniej Alexis de Tocqueville, do którego doktryny komunitarianie wielokrotnie powracają $^{12}$. Uważają, że człowiek nadto skupia się na poszukiwaniu swojego niepowtarzalnego stylu życia, powołania, systemu wartości, czyli własnej autoekspresji. Wynika to z błędnego, ich zdaniem, założenia, promowanego przez liberałów, o autonomicznym charakterze natury ludzkiej ${ }^{13}$.

Taka liberalna perspektywa determinuje państwo, by było aksjologicznie neutralne i określało jedynie, według jakich procedur ludzie powinni rozpatrywać spory jednostkowe oraz zbiorowe ${ }^{14}$. Dlatego komunitarianie krytykują liberalną koncepcję państwa, upatrując w niej instytucję proceduralną, w której sprawiedliwość pojęta jest jedynie formalnie ${ }^{15}$. Uprawnienia człowieka nie są

9 Zagadnienie klasyfikacji odmian komunitaryzmu nie stanowi przedmiotu badań niniejszego artykułu. Szerzej o występujących w literaturze przedmiotu próbach klasyfikacji analizowanej doktryny: D. Karnowska, Spór o wspólnoty. Idee komunitarystyczne we współczesnej polskiej myśli politycznej, Toruń 2011, s. 25-28.

10 Ch. Taylor, Etyka autentyczności, Kraków 2002, s. 60.

11 S. Czarnecki, Czy liberalizm deprecjonuje wspólnotę?, [w:] Indywidualizm, wspólnotowość, polityka, red. M.N. Jakubowski, A. Szahaj, K. Arbiszewski , Toruń 2002, s. 164-465.

12 Ch. Taylor, Etyka..., s. 16-17; R. Frost, Contexts of Justice. Political Philosophy beyond Liberalism and Communitarianism, Los Angeles 2002, s. 114-116; szerzej o doktrynie Alexisa de Tocqueville'a: M. Tracz-Tryniecki, Myśl polityczna i prawna Alexisa de Tocqueville, Kraków 2009.

13 A. Gawkowska, Jak rozwiewać obawy liberałów? O nie(dość)wykorzystanych zasobach teorii wspólnotowych, [w:] Teorie wspólnotowe a praktyka spoleczna. Obywatelskość, polityka, lokalność, red. A. Gawkowska, P. Gliński, A. Kościański, Warszawa 2005, s. 52.

14 B. Breslin, Communitarian Constitution, Baltimore 2004, s. 19-21; S. Mulhal, Articulating the Horizons of Liberalism: Taylor's Political Philosophy, [w:] Charles Taylor, red. R. Abbey, Cambidge 2004, s. 114.

15 S. Krzyżaniak, Jednostka, wspólnota, społeczeństwo. Dyskusje wobec współczesnego uporządkowania społecznego, Zielona Góra 2003, s. 107-109. 
bowiem ani wyprowadzane, ani uzasadniane jakąkolwiek koncepcją dobrego życia. Sprawiedliwe społeczeństwo dla liberałów nie sprzyja jakimkolwiek cnotom oraz szczególnym celom. Raczej dostarcza ogólnych ram prawnych, które są neutralne wobec indywidualnych ludzkich celów określających każdemu człowiekowi wizję dobrego życia ${ }^{16}$. Jak zauważył Sławomir Czarnecki: „Metaforycznie rzecz ujmując: zajęci tworzeniem politycznych ram liberałowie zapomnieli wypełnić je płótnem, na którym powstaje obraz życia społecznego" ${ }^{17}$. W takim ujęciu państwo liberalne jest traktowane przez obywateli jako jedna z wielu instytucji usługowych, która w zamian za pewne świadczenia jest zobowiązana do zapewnienia przyjętych na siebie zobowiązań ${ }^{18}$. Powoduje to, że lojalność wobec państwa ma charakter warunkowy i jest woluntarystyczna.

Zdaniem komunitarian doprowadziło to wystąpienia zjawiska depolityzacji, oznaczającego wycofanie się obywateli z aktywnego życia publicznego. Polityka została oddana w ręce zawodowych polityków oraz organów administracji publicznej. Takie proceduralne państwo nie jest w stanie zagwarantować obiecywanej jednostkom wolności, ponieważ nie potrafi samodzielnie rozbudzić obywatelskiego zaangażowania, jakiego wymaga aktywne uczestnictwo w demokratycznej wspólnocie. Dlatego komunitarianie, podobnie jak konserwatyści oraz przedstawiciele radykalnej lewicy, uważają że współczesny liberalizm jest doktryną dążącą do autodestrukcji. Argumentują bowiem, że trwałość ładu wolnościowego nie zależy tylko od instytucji politycznych i prawnych, ale także od kultury i obyczaju społecznego ${ }^{19}$. Ponadto zarzucają liberałom, że ci przedstawiają nadmiernie uproszczoną, a przez to i nierzeczywistą wizję jednostki. Na płaszczyźnie konstrukcji metodologicznych sprzeciwiają się natomiast kontraktualistycznemu modelowi powstania, budowy i funkcjonowania społeczeństwa i państwa ${ }^{20}$. Występują również przeciw liberalnym projektom racjonalistycznym i utylitarnym. Podsumowując dotychczasowe rozważania, należy podkreślić, że komunitariańska krytyka liberalizmu sprowadza się zatem do dwóch płaszczyzn - pierwsza z nich dotyczy liberalnej praktyki deprecjonującej wartość wspólnoty; druga natomiast odnosi się do liberalnej teorii, która falsyfikuje realia społeczne ${ }^{21}$.

16 P. Śpiewak, Poszukiwanie wspólnot, [w:] Komunitarianie..., s. 6; D. Bell, Communitarianism and its Critics, Oxford 1993, s. 93.

17 S. Czarnecki, op., cit., s. 174.

18 P. Śpiewak, op. cit., s. 6.

19 Ibidem, s. 7.

20 M.J. Sandel, Liberalizm a granice sprawiedliwości, Warszawa 2009, s. 169-209; A. Gawkowska, Komunitariańska krytyka kontraktualizmu, [w:] Umowa społeczna i jej krytycy w myśli politycznej i prawnej, red. Z. Rau, M. Chmieliński, Warszawa 2010, s. 422-430; A. Szahaj, Jednost$k a \ldots$, s. 161-163.

21 R. Prostak, Liberalna autonomia, komunitarystyczna heteronomia. Charles Taylor jako krytyk teorii Sprawiedliwości Johna Rawlsa, [w:] Aktualność wolności. Wybór tekstów, red. P. Śpiewak, Warszawa 2005, s. 241. 
Wizja człowieka we wspólnocie. Podstawowym założeniem komunitarian jest teza, znana ludzkości już od czasów Arystotelesa, że człowiek jest istotą żyjącą we wspólnocie ${ }^{22}$. Rzetelność naukowa nakazuje, aby doprecyzować pojęcie wspólnoty, pomimo tego, że jest ono powszechnie i intuicyjnie zrozumiałe. Na potrzeby niniejszego wywodu przyjmuję, że wspólnota to grupa ludzi zamieszkujących razem określone terytorium, którzy mają wspólną historię, podzielają te same wartości, współuczestniczą $\mathrm{w}$ różnorodnych aktywnościach (szczególnie publicznych) oraz charakteryzują się wysokim stopniem solidarności ${ }^{23}$. Wynika $\mathrm{z}$ tego, że tylko dzięki osadzeniu jednostki we wspólnocie ma ona możliwość poznania siebie i swojej tożsamości. Jest więc zdeterminowana przez posiadanie z innymi ludźmi wspólnej historii, instytucji politycznych, porządku prawnego, języka oraz wrażliwości moralnej ${ }^{24}$. Należy jednak podkreślić, że perspektywa komunitariańska uwzględnia zarówno godność jednostki ludzkiej, jak i społeczny wymiar jej życia ${ }^{25}$.

Wspólnotę charakteryzują dwie podstawowe cechy: wspólne praktyki (określone przez Amitaia Etzioniego mianem ,powiązanych relacji międzyludzkich zabarwionych elementem emocjonalnym"26) oraz pamięćc ${ }^{27}$. Pierwsze $\mathrm{z}$ wymienionych orientują ludzi $\mathrm{w}$ otoczeniu oraz nadają porządek ich postępowaniu. Każda praktyka ma bowiem swoje wewnętrzne kryteria ocen, które możemy określić też mianem umiejętności. Dotyczy to każdej ludzkiej aktywności, jak i życia we wspólnocie ${ }^{28}$. Dlatego od wspólnoty nie da się uciec. Można w jej obrębie konkurować, spierać się o to, kto jest lepszy w danej dziedzinie, wzbogacać wiedzę, ale i tak każda konkretna postawa, wypowiedź, czy aktywność jest zrozumiała tylko przez odniesienie do szerszej sfery praktyk konstytuujących wspólnotę. Drugą wymienioną cechą wspólnoty jest pamięć obecna w historii wspólnych praktyk. Zdaniem komunitarian człowiek nie składa się tylko z teraźniejszości i przyszłości. To nasza przeszłość i jej historyczna narracja stanowi o tym, kim jesteśmy i jak sami siebie postrzegamy w obszarze rzeczonych wspólnych praktyk (tzw. narracyjna koncepcja jaźni MacIntyre'a ${ }^{29}$ ). Opowiadając historię, nie tylko sytuujemy ją w czasie, ale także w przestrzeni międzyludzkiej - kiedy uzasadniamy swoje postępowanie, wskazujemy na postawy, oczekiwania czy wymogi prakty-

${ }^{22}$ Komplementarnej analizy dotyczącej wizji jednostki według komunitarian dokonał: W. Kymlicka, Liberalism, Community and Culture, Oxford 1991, s. 47-73.

${ }_{23}$ D.L. Philips, Looking Backward. A Critical Appraisal of Communitarian Thought, Princeton 1993, s. 14; R. Prostak, Rzecz..., s. 36-37.

${ }^{24}$ S. Krzyżaniak, op. cit., s. 110.

25 T. Buksiński, Wspótczesne filozofie polityki, Poznań 2006, s. 92.

${ }^{26}$ A. Etzioni, The New Golden Rule: Community and Morality in a Democratic Society, New York 1996, s. 127.

${ }^{27}$ P. Śpiewak, op. cit.,s. 9.

${ }^{28}$ T. Buksiński, op. cit., s. 81-82.

${ }^{29}$ A. MacIntyre, Dziedzictwo cnoty. Studium z teorii moralności, Warszawa 1996, s. 388. 
ki społecznej. Toteż interpretacje wspólnego życia, dokonywane przez różne narracje, przedstawiają odmienne interpretacje charakterów, celów i wartości wspólnot. Dzięki temu można odkryć różne motywy ludzkiego postępowania $^{30}$. Dlatego żadnej opowieści, nawet dotyczącej historii kraju, nie da się zredukować do prostej prawdy ${ }^{31}$. Wartość i cel opowieści leży bowiem w samym jej opowiadaniu, ponieważ porządkując wydarzenia historyczne, poznajemy także praktyki i losy żyjących w nim ludzi ${ }^{32}$. Komunitarianie podkreślają więc, że poszukiwanie uniwersalnych aksjomatów, motywowane potrzebą uzyskania pewności, zawsze odbywa się z jakiejś zindywidualizowanej perspektywy.

Podsumowując dotychczasowe rozważania, trzeba zauważyć, że wspólnoty nakładają się na siebie i współistnieją ze sobą ${ }^{33}$. Są realnym, chociaż często nieuświadomionym faktem społecznym. Dlatego samookreślenie się człowieka nie wynika, jak uważają liberałowie, tylko z dokonywanych przez niego wyborów, ale jest zdeterminowane praktykami społecznymi i dyskursem zbiorowym, czyli innymi słowy prowadzi to do wniosku, że wspólna przestrzeń rozmowy wyznacza sens pojęć, jakimi się posługujemy. Przykładowo, nie można w pełni zrozumieć pojęcia sprawiedliwości, wolności, czy tolerancji poza kontekstem znaczeniowym charakterystycznym dla każdej wspólnoty.

Należy jednak podkreślić, że komunitarianie nie przekreślają całkowicie indywidualizmu, ale postrzegają go w bardziej uspołecznionej wersji, nie można bowiem wyobrazić sobie moralnej istoty ludzkiej poza społeczeństwem, w którym została ona ukształtowana ${ }^{34}$. Zdaniem komunitarian, jeśli człowiek spojrzy na siebie przez pryzmat zbiorowych praktyk, to zda sobie sprawę z ich wagi dla wspólnej tożsamości. Dzięki temu nabierze znaczenia jego troska o wspólnotę, której najlepszym wyrazem jest cnota patriotyzmu ${ }^{35}$. Przejawami tejże cnoty jest ochrona własnej kultury, zasobów i interesów narodowych. Poczucie związku ze wspólnotą, jej prawami i historią jest koniecznym warunkiem podjęcia wspólnych działań postrzeganych jako obowiązków obywatelskich $^{36}$. Dlatego patriotyzm jest zobowiązaniem i postacią społecznej dyscypliny. Zapewnia identyfikację z dobrem wspólnym oraz lojalność wobec

30 A. Chmielwski,Wprowadzenie. Filozofia moralności Alasdaira MacIntyre 'a, [w:] A. MacIntyre, Dziedzictwo cnoty. Studium z teorii moralności, Warszawa 1996, s. XXIX-XXX.

31 A. MacIntyre, Czyja sprawiedliwość Jaka racjonalność?, Warszawa 2007, s. 56-57.

32 A. Chmielewski, MacIntyre a współczesna filozofia polityczna, [w:] A. MacIntyre, Dziedzictwo cnoty..., s. 22-23.

33 M. Król, Filozofia polityczna, Kraków 2008, s. 210-211.

34 D. Drałus, Charles Taylor. Sprzeczności pomiędzy filozofia a praktyka polityczną, [w:] Indywidualizm, wspólnotowość, polityka, s. 237-238.

35 A. MacIntyre, Dziedzictwo cnoty. Studium z teorii moralności, Warszawa 1996, s. 451-452.

36 A. Gawkowska, Samorząd zobowiązanych obywateli (Michaela J. Sandela tęsknota za republikanizmem), [w:] Indywidualizm, wspólnotowość, polityka, s. 250-251. 
członków wspólnoty ${ }^{37}$. Dla liberałów pojęcie dobra wspólnego pozbawione jest sensu, ze względu na niemożliwość ustalenia jego zakresu oraz definicji i może jedynie stanowić uzasadnienie ograniczenia wolności jednostki. Z kolei dla komunitarian dobrem wspólnym może być porządek prawny chroniący uprawnienia obywateli, kultura, tradycja wspólnot narodowych oraz wolność w ujęciu republikańskim ${ }^{38}$. Nie można bowiem mówić, jak chcieliby liberałowie, o uniwersalnych zasadach etycznych jako o podstawie samorealizacji człowieka, gdyż zasady te muszą pierwotnie znaleźć oparcie w praktycznym działaniu, które w konkretnym społeczeństwie nada im właściwych sobie treści. Innymi słowy, zasady moralne nie są wyabstrahowane, lecz nabierają określonego kształtu w warunkach danego społeczeństwa. Są one dopiero zrozumiałe w obrębie moralnego i kulturowego doświadczenia etnicznych wspólnot historycznych ${ }^{39}$. Członkowie tak postulowanej przez komunitarian wspólnoty obywatelskiej podzielają wspólne wzorce wartości i przekonania moralne, które wyznaczają obszar wspólnej refleksji, wrażliwości i odpowiedzialności.

Wizja państwa. Liberalizm jest dla komunitarian pewnym historycznym osiągnięciem związanym z dziedzictwem instytucji politycznych, które ukształtowało nasze współczesne myślenie i praktykę ${ }^{40}$. Doktryna liberalizmu nie może jednak stanowić jedynej uniwersalnej zasady, na bazie której funkcjonuje społeczeństwo. Dlatego dla komunitarian wolność jednostki zależy od aktywnego wspierania instytucji społeczeństwa obywatelskiego. Człowiek, który identyfikuje się ze swoją wspólnotą, pragnie politycznie partycypować w życiu swego kraju ${ }^{41}$. Należy zaznaczyć, że jednocześnie komunitarianie nie narzucają żadnej konkretnej orientacji politycznej. Przeprowadzona analiza ich podstawowych założeń doktrynalnych pozwala jednak dostrzec eklektyczne połączenie elementów konserwatywnych (tradycja, wspólnota),

37 Ch. Taylor, Nieporozumienia wokól debaty liberalno-komunitariańskiej, [w:] Komunitarianie..., s. 47, 53, 63-64; A. Szahaj, M. N. Jakubowski, Filozofia polityki, Warszawa 2005, s. 145.

38 Jak napisał Will Kymlicka: „Tymczasem w społeczeństwie komunitarystycznym dobro wspólne jest pojmowane jako materialna koncepcja dobrego życia, która wyznacza wspólnotowy styl życia. To dobro wspólne ma dostarczać kryterium oceny indywidualnych preferencji, a nie odzwierciedlać ich strukturę", za: W. Kymlicka, Współczesna filozofia polityczna, Warszawa 2009, s. 273; por. R. Abbey, Charles Taylor, Princeton 2000, s. 114-116.

39 A. Gawkowska, Biorac wspólnotę poważnie?, Warszawa 2004, s. 82-85.

$40 \mathrm{Na}$ uwagę zasługuje koncepcja Michaela Walzera, który odróżnił istnienie zasad moralnych uniwersalnych (np. nie zabijaj), opisując je mianem słabych, płytkich czy „rozrzedzonych” (thin), od zasad moralnych partykularnych określonych wspólnot, które są mocne, głębokie i gęste (thick). Wszystkie zasady uniwersalne pochodzą od partykularnych wspólnot i są tym, co je ze sobą łączy. Tak rozumiany uniwersalizm nie jest zbieżny z jego odpowiednikiem występującym w teorii liberalnej, uznającym jedność natury ludzkiej; szerzej: M. Walzer, Thick and Thin: Moral Argument at Home and Abroad, Notre Dame 1994; A. Gawkowska, Biorac ..., s. 60-75.

41 T. Buksiński, op. cit., s. 89. 
republikańskich (cnoty obywatelskie, dobro wspólne), socjalistycznych (brak zaufania do mechanizmów wolnorynkowych, sprawiedliwość społeczna), demokratycznych (samorządność, partycypacja polityczna) jak i liberalnych (negacja inżynierii społecznej, poszanowanie wolności jednostki).

Dobre państwo, jak i dobre społeczeństwo, wiążą się dla komunitarian z ideą samorządności, rozproszoną władzą, lokalnością oraz obywatelską partycypacją w życiu publicznym ${ }^{42}$. Jest to państwo i społeczeństwo ulegające przemianom, ponieważ podlega ciągłej kontekstualizacji (oznaczającej, że zrozumienie określonej idei wymaga umieszczenia jej w szerszym kontekście przez odniesienie do kodów kultury) ${ }^{43}$. W Komunitariańskiej platformie programowej można odnaleźć sformułowanie głoszące, że: „Komunitarianie nie opowiadają się za rządami większości. Sukces demokratycznego eksperymentu polegający na zapewnieniu uporządkowanej wolności (nie zaś nieograniczonej samowoli), zależy nie od dekretów czy siły, ale od wykształcenia społecznie podzielanych wartości, obyczajów i praktyk, które gwarantują wzajemne poszanowanie praw jednostkowych oraz regularne wypełnianie osobistych, obywatelskich i zbiorowych powinności. (...) zarazem zróżnicowanie stanowisk moralnych nie musi prowadzić do kakofonii. Rzeczywisty dialog może doprowadzić do wyłonienia się wyrazistych opinii oraz rozpoznania i rozwinięcia wspólnych aspiracji"44. Taka wizja demokracji deliberatywnej oparta jest na postrzeganiu społeczeństwa obywatelskiego i opinii publicznej, jako podmiotu, który powstaje w wyniku refleksji i dyskusji zbiorowej ${ }^{45}$. Trafnie ilustrują to słowa Michaela Walzera, który napisał, że: „Społeczeństwo obywatelskie jest rzeczywiście szkołą - szkołą tolerancji i współistnienia w warunkach rywalizacji, można stwierdzić, że uczy ducha obywatelskiego"46. Jest więc to wspólnota ludzi, którzy nie musieli się kiedykolwiek osobiście spotkać, ponieważ mogą pozostawać ze sobą w kontakcie dzięki środkom technologicznym ${ }^{47}$.

Wspomniana opinia publiczna nie zastępuje władzy publicznej, ale ją nadzoruje i hamuje. Stanowi zatem obszar racjonalnego dyskursu o władzy, skierowanego właśnie do władzy. Wynika z tego, że tak rozumiana opinia publiczna

42 P. Śpiewak, op. cit., s. 14; M. Redhead, Charles Taylor. Thinking and Living Deep Diversity, Boston 2002, s. 105-108.

43 A. Gawkowska, Biorac ..., op. cit., s. 129-130.

44 Komunitariańska platforma programowa..., s. 19.

45 Szerzej o komunitariańskiej wizji demokracji deliberatywnej: M. Walzer, Polityka i namiętność. O bardziej egalitarny liberalizm, Warszawa 2006, s. 136-162.

46 Ibidem, s. 111.

47 Sam społeczny dyskurs polityczny nie stanowi przedmiotu badań niniejszego artykułu, należy jednak zaznaczyć, że nie wszyscy członkowie wspólnoty powinni być do niego dopuszczeni. Szerzej o zjawiskach wykluczenia i nietolerancji niezbędnych dla prowadzenia racjonalnego dialogu społecznego: A. MacIntyre, Etyka i polityka, Warszawa 2009, s. 303-312; zagadnieniu temu poświęcona jest także rozprawa M. Walzera, O tolerancji, Warszawa 1999. 
tworzy podstawę społecznego istnienia, nadając mu tożsamość i wyznaczając cele funkcjonowania państwa. Zdaniem komunitarian kierowanie współczesnym państwem wymaga nieustannego dbania o zachowanie równowagi pomiędzy sprzecznymi społecznymi roszczeniami, m.in. przez poszukiwanie nowych rozwiązań, które pozwolą na utrzymanie tejże wspólnotowej homeostazy. Dlatego należy podkreślić, że ocena reguł funkcjonujących $\mathrm{w}$ danej wspólnocie nie może być dokonywana w oparciu o kryteria uniwersalne i zewnętrzne wobec niej samej. Jak zauważył Michael Walzer: „Demokracja jest (...) politycznym sposobem rozdzielania władzy. Wszelka relacja zewnętrzna jest wykluczona. Liczy się debata między obywatelami”"48. Wynika $\mathrm{z}$ tego, że legitymizacja władzy oparta jest bowiem na pozytywnej ocenie rezultatów jej funkcjonowania dokonanej przez społeczeństwo ${ }^{49}$. Komunitarianie popierają więc demokrację substancjalną, a nie proceduralną, z zaznaczeniem, że wyznawane publiczne wartości nie mają charakteru abstrakcyjnego lecz pochodzą wprost ze społecznego dyskursu ${ }^{50}$. Dlatego wśród przedstawicieli komunitaryzmu można spotkać się z negacją tezy o niepodzielności suwerenności państwa, połączonej z postulatem decentralizacji organów rządowych, których terenowe struktury umożliwiłyby prowadzenie lokalnego dyskursu politycznego ${ }^{51}$. Oczywiście funkcjonowanie takich wspólnot możliwe jest wyłącznie tam, gdzie ludzi łączy silne poczucie przynależności grupowej.

III. Wolność słowa z perspektywy komunitarianizmu. Problematyka wolności słowa nie stanowiła dla komunitarian pierwszoplanowego obiektu zainteresowań. W Komunitariańskiej platformie programowej odnajdziemy jedynie sformułowanie, że wolność słowa gwarantowana Pierwszą Poprawką do konstytucji Stanów Zjednoczonych Ameryki jest tak samo bliska komunitarianom, jak i libertarianom oraz wszelkim innym Amerykanom ${ }^{52}$. Dlatego nie można ograniczać prawnie swobody wypowiedzi nawet takich, które mają charakter rasistowski, seksistowski czy w innym stopniu znieważający. Istnieje bowiem możliwość zastosowania pozaprawnych środków wyrażających dezaprobatę wobec mowy nienawiści oraz propagujących wśród obywateli tolerancję.

Szczególną uwagę temu zagadnieniu poświecił Jeffrey Abramson wraz z Elizabeth Bussiere w artykule Wolność stowa i prawo do swobodnego przekazu. Perspektywa Komunitariańska opublikowanym w 1995 r. Na wstępie należy jednak zaznaczyć, że tak większość komunitariańskiej refleksji, jak i przemy-

${ }^{48}$ M. Walzer, Sfery sprawiedliwości. Obrona pluralizmu i równości, Warszawa 2007, s. 460.

49 W. Kymlicka, Wspótczesna..., s. 309.

${ }^{50}$ D. Karnowska, op. cit., s. 67.

${ }^{51}$ H. Tam, Komunitaryzm. Nowy program polityczny i obywatelski, Toruń 2011, s. 218.

52 Szerzej o politycznych i historycznych uwarunkowaniach dotyczących normowania zakresu wolności słowa w USA: M. Urbańczyk, Liberalna doktryna wolności słowa a swoboda wypowiedzi historycznej, Poznań 2009, s. 57-68. 
ślenia wspomnianych autorów dotyczą przede wszystkim współczesnej sytuacji społeczno-politycznej Stanów Zjednoczonych Ameryki. Abramson i Bussiere odwołali się do wspomnianej już Pierwszej Poprawki, według której: „Kongres nie ustanowi ustaw wprowadzających religię lub zabraniających swobodnego wykonywania praktyk religijnych; ani ustaw ograniczających wolność słowa lub prasy, lub naruszających prawo do pokojowych zgromadzeń i wnoszenia do rządu petycji o naprawę krzywd". Zdaniem wymienionych autorów istnieją dwie konkurencyjne interpretacje tejże Poprawki. Według pierwszej z nich, wyrażającej „libertariańskie koncepcje polityczne”, władza nie powinna w żaden sposób ingerować w niczyje wypowiedzi i publikacje. Jedynie niezależne jednostki samodzielnie decydują, czyje poglądy warte są wysłuchania. Jednocześnie Pierwsza Poprawka gwarantuje też wszelkim mediom prawo do prowadzenia niezależnej i niczym nieskrępowanej polityki redakcyjnej ${ }^{53}$.

Druga interpretacja związana jest natomiast $\mathrm{z}$ „komunitariańskimi koncepcjami politycznymi”. Według niej naczelną wartością demokratyczną jest: „aby podstawowe kanały komunikacji masowej były otwarte dla ogółu obywateli i aby tocząca się w mediach debata polityczna dopuszczała do głosu tak szerokie spektrum opinii, jak to tylko z praktycznego punktu widzenia jest możliwe" ${ }^{54}$. Wynika z tego, że w erze istnienia olbrzymich medialnych koncernów konieczne staje się dla zagwarantowania faktycznej możliwości społeczno-politycznego dyskursu, wprowadzenie ze strony państwa norm prawnych regulujących dostęp do publicznych kanałów komunikacji. Należy jednocześnie zaznaczyć, że prezentowana druga interpretacja nadal zawiera postulat niezależności funkcjonowania mediów od ingerencji ze strony władzy publicznej. Tak rozumiana wolność słowa, o silnym liberalnym i negatywnym charakterze, jest jednak wtórna wobec pozytywnej wolności dostępu do środków przekazu przysługującej niejako całej wspólnocie ${ }^{55}$. Zabezpieczenie korzystania z wolności słowa ma według komunitarian nie tylko indywidualny, ale również i wspólnotowy charakter, ponieważ służy ocenie i wyrażaniu krytycznych uwag pod adresem rządzących. Jak już było to wcześniej wyjaśnione, to właśnie opinia publiczna w drodze społecznego dyskursu tworzy wspólnotową tożsamość i wyznacza cele władzy ${ }^{56}$. Istnienie przestrzeni medialnej pozwalającej na swobodną artykulację i wymianę zdań jest zatem koniecznym elementem istnienia społeczeństwa obywatelskiego w rozumieniu komunitarian ${ }^{57}$.

Abramson i Bussiere zauważyli, że od lat sześćdziesiątych XX w. zarówno w orzecznictwie sądowym, jak i w praktyce funkcjonowania organów admi-

${ }_{53}$ J. Abramson, E. Bussiere, Wolność stowa i prawo do swobodnego przekazu..., s. 373.

${ }^{54}$ Ibidem, s. 373-374.

55 Szerzej o komunitariańskiej argumentacji dotyczącej prawa do bycia wysłuchanym w publicznej debacie: E. Frazer, op. cit., s. 227-229.

56 P. Śpiewak, op. cit., s. 14.

${ }^{57}$ H. Tam, op. cit., s. 131-132. 
nistracyjnych (np. FCC - Federal Communications Commision) zaczęła dominować libertariańska interpretacja Pierwszej Poprawki, akcentująca przede wszystkim to, że państwo nie może dokonywać moralnych osądów społecznie szkodliwych wypowiedzi. Jednocześnie przywoływani autorzy wskazali na zniesienie tzw. doktryny bezstronności, zawartej w uchwalonej w 1934 r. Communication Act, która została uchylona przez FCC w 1987 r. Była to regulacja prawna wymagająca od nadawców, aby przeznaczali określony czas antenowy na prezentację treści istotnych z punktu widzenia interesu publicznego. Ratio legis wprowadzenia takiego uregulowania wynikało z uznania częstotliwości fal radiowych za własność publiczną. Toteż uzyskanie koncesji pozwalającej na nadawanie programów radiowych i telewizyjnych wiązało się ze zobowiązaniem nadawcy do emitowania treści społecznie istotnych. Drugim obliczem „doktryny bezstronności” był obowiązek ciążący na stacjach radiowych i telewizyjnych, nakazujący im, aby osoby, które były na ich falach personalnie atakowane, miały możliwość wygłoszenia darmowej repliki. Podkreślano bowiem prymat możliwości widzów i słuchaczy do poznania stanowiska obu stron danej sprawy nad prawami nadawców do decydowania o treści emitowanych programów. Uchylenie tego aktu w 1987 r. uzasadniano uwolnieniem mediów od odgórnej regulacji, podkreślając jednoczenie, że rynkowa konkurencja zaspokoi wszelkie potrzeby demokratycznego społeczeństwa.

Tak rozumiana przez komunitarian wolność słowa rozpatrywana jest zatem z perspektywy szeroko rozumianego dobra wspólnego. Dlatego wiąże się ona bezpośrednio z problematyką dostępu do mediów. Liberalni zwolennicy deregulacji dostępności do mediów słusznie zauważają, że dynamicznie postępujący rozwój technologiczny tworzy nieustannie nowe obszary wyrażania swoich poglądów, jak i zdobywania informacji. Komunitarianie tymczasem zwracają uwagę na niedostrzegane przez liberałów i libertarian zjawisko koncentracji własności, występujące zarówno wśród właścicieli starych, jak i nowych mediów ${ }^{58}$. Jednocześnie są otwarci na wykorzystanie nowych kanałów komunikacyjnych. Jak napisał Henry Tam: „Technologia interaktywna powinna zostać użyta w celu zrównoważenia konwencjonalnych dwustronnych debat prowadzonych przez rywalizujących ze sobą ekspertów lub polityków przez stworzenie obywatelom możliwości uczestnictwa w dyskusjach grupowych oraz wypytywania ekspertów o kwestie techniczne" 59 . Interaktywne media stają się więc doskonałym środkiem pozwalającym nie tylko na zdobywanie informacji i wiedzy, ale także na wymianę poglądów i uwrażliwienie obywateli na faktycznie występujące w ich społeczeństwie problemy ${ }^{60}$.

58 Wolność stowa i prawo do swobodnego przekazu..., s. 384.

59 H. Tam, op. cit., s. 135.

60 Wiąże się to z zagadnieniem tzw. wspólnoty responsywnej, szerzej: A. Etzioni, Wspólnota responsywna..., s. 181-203. 
Analizując problematykę wolności słowa, należy także zastanowić się nad tym, gdzie leżą jej granice? Zagadnienie to poruszył Sandel, który poszukując odpowiedzi na postawione powyżej pytanie, porównał liberalizm z komunitaryzmem. Jego zdaniem: „Liberałowie argumentują, że państwo musi zachować neutralność wobec opinii wyrażanych przez obywateli. Państwo może regulować czas, miejsce i sposób wypowiedzi - może zakazać hałaśliwego zlotu w środku nocy - nie może jednak wkraczać w jej treść. Zakaz mowy obraźliwej czy źle odbieranej narzuca jednym wartości innych, przez co nie szanuje prawa każdego obywatela do swobody posiadania i wyrażania własnych poglądów"61. Podstawą takiego stanowiska jest liberalna koncepcja osoby, zgodnie z którą przyrodzona godność jednostki nie jest pochodną żadnej ze społecznych ról jakie człowiek pełni. Wynika z tego, że obelgi, które są adresowane wobec grupy, z którą jednostka się identyfikuje, teoretycznie nie naruszają jej godności, albowiem poszanowanie samego siebie jest pierwotne względem więzi społecznych. Żadne zniewagi, które nie są bezpośrednio kierowane w stosunku do człowieka, nie mogą naruszyć jego godności. Dlatego jedynym możliwym ograniczeniem wolności słowa dla liberałów jest sytuacja, w której mowa nienawiści powoduje powstanie rzeczywistej fizycznej szkody (niezależnej od samych wypowiedzianych słów) ${ }^{62}$. Zdaniem Sandela przeciwieństwem liberalnej koncepcji granic wolności słowa jest jej komunitariański odpowiednik, według którego można wyrządzić jednostce szkodę równie dotkliwą jak rzeczywista, jeśli obrazi się grupę etniczną lub religijną, z którą ta jednostka się identyfikuje. Dla komunitarian istotna jest zatem waga moralna konkretnej wypowiedzi w odniesieniu do moralnej tożsamości ludzi (uwarunkowanej zakorzenieniem w danej wspólnocie), którzy mogą być tymi słowami urażeni. Zatem w przeciwieństwie do liberałów postulujących zachowanie neutralności wobec treści wypowiedzi, komunitarianie dopuszczają jej ograniczenie, powołując się na dominujące wartości, które są wyznawane w określonej wspólnocie ${ }^{63}$. Podobnie odniósł się do tego zagadnienia MacIntyre: „Z tego, co powiedziałem, wynika oczywiście, że chociaż państwo musi być tolerancyjne, to nie może narzucać tolerancji innym. Lokalna wspólnotowa autonomia wymaga wolności podejmowania własnych decyzji o tym, gdzie przeprowadzić granicę między wypowiedzią, którą można tolerować, a wypowiedzią, której tolerować nie można"64. Decydującą rolę w dookreśleniu granic wolności słowa powinny zatem odgrywać wspólnoty na poziomie

61 M. J. Sandel, op. cit., s. 31-34.

62 Dobitym przykładem zastosowania takiej argumentacji jest wyrok wydany w USA w sprawie Collin v. Smith, 447 F.Supp. 676 (1978), oraz Collin v. Smith, 578 F2d 1198 (1978), w którym Sąd Apelacyjny powołując się na Pierwszą Poprawkę uznał zakaz przemarszu neonazistów za niekonstytucyjny (sic!).

${ }^{63}$ M.J. Sandel, op. cit., s. 33.

64 A. MacIntyre, Etyka ..., s. 311. 
lokalnych autonomii, ponieważ są one najbardziej reprezentatywne względem wartości wyznawanych przez ich członków.

Przyczyną istnienia omawianej dychotomii stanowisk jest fundamentalna różnica $\mathrm{w}$ definiowaniu pojęcia wolności przez liberałów (oraz libertarian) i komunitarian. Dla pierwszych wolność człowieka, a zatem i pochodna jej wolność słowa, to „sytuacja, w której władze nie ograniczają dokonywanych przez jednostki indywidualnych wyborów wartości”"65. Wynika to z założenia, że człowiek jest wyłącznym autorem podejmowanych decyzji, a zatem, że nikt nie ma i nie może mieć, wpływu na jego preferencje ${ }^{66}$. Tymczasem dla komunitarian wolność to współuczestnictwo w samorządzie nad całą wspólnotą (tzw. wolność obywatelska) ${ }^{67}$. Tylko w ten sposób jednostka może uzyskać wiedzę o samej sobie i mieć wpływ na kształtowanie szeroko rozumianego dobra wspólnego całego społeczeństwa ${ }^{68}$. Jak napisali Abramson i Bussiere: „To idea samorządu, a nie idea autoekspresji, pozostawała aż do lat sześćdziesiątych głównym uzasadnieniem wolności słowa"69. Oznacza to, że dla komunitarian wolność słowa nie jest jedynie indywidualną wolnością człowieka, ale w swoim społecznym wymiarze stanowi ona instrument służący zapewnieniu prawidłowego funkcjonowania ustroju demokratycznego. Dlatego konkludując wywód poświęcony komunitariańskiej wizji wolności słowa, należy zauważyć, że spełnia ona trzy funkcje - po pierwsze, zezwala na prowadzenie społecznego dyskursu politycznego; po drugie, pozwala wspólnocie na ocenę sprawowanej władzy publicznej; oraz po trzecie, jest środkiem pozwalającym na propagowanie obywatelskich cnót oraz praktyk samorządu.

IV. Konkluzje. Na podstawie przeprowadzonego wywodu zasadne staje się postawienie pytania, czy można mówić o istnieniu jednej wspólnej definicji pojęcia wolności słowa, czy też nie byłoby właściwsze stwierdzenie, że mamy do czynienia z całym spektrum różnych od siebie wolności słowa? Otóż w mojej opinii przedstawiona przez komunitarian wizja jednostki zakorzenionej w licznych przenikających się wzajemnie wspólnotach, z których najszerszą jest społeczeństwo żyjące w danym państwie, oznacza, że każda wspólnota posiada własną wyjątkową specyfikę. Skoro różne wspólnoty, spo-

65 Wolność słowa i prawo do swobodnego przekazu..., s. 387.

66 Z. Rau, Liberalizm. Zarys myśli politycznej XIX i XX wieku, Warszawa 2000, s. 12-13.

67 M. Turowski, Liberalizm po komunitaryzmie? Filozoficzne koncepcje jednostki, wspólnoty i państwa jako źródlo krytyki społecznej i politycznej, Toruń 2011, s. 88-92; Ch. Taylor, Nieporozumienia..., s. 53.

68 J. Zdybel, Między wolnościa a powinnością. Filozofia polityczna Isaiaha Berlina $i$ Alasdaira MacIntyre'a, Lublin 2005, s. 241-260; A. Szahaj, Charles Taylor on Freedom, [w:] Charles Taylor's Vision of Modernity: Reconstructions and Interpretations, red. Ch. Grabowski, J. Hudzik, J. Kłos, Cambridge 2009, s. 154-163.

69 Wolność słowa i prawo do swobodnego przekazu..., s. 377. 
łeczeństwa, czy cywilizacje odwołują się do odmiennych wizji sprawiedliwości i moralności to oznacza, że dysponują różnorodnymi poglądami na to kiedy, w jakich warunkach i z jaką intensywnością wcielać je w życie ${ }^{70}$. Analogicznie należy rozumować w odniesieniu do problematyki wolności słowa. Nie istnieje żadna uniwersalna, aksjologicznie neutralna i nadrzędna wobec partykularnych porządków społecznych reguła głosząca, jaki jest zakres wolności słowa przysługujący każdemu człowiekowi ${ }^{71}$. Jest tak, ponieważ nie istnieje żaden wyabstrahowany od swojej wspólnoty człowiek. Inną wolnością słowa będzie cieszył się amerykański libertarianin, inną północnokoreański opozycjonista, inną iracki szyita, a jeszcze inną polski adiunkt zatrudniony w publicznej uczelni wyższej.

Różnorodność cywilizacyjna, religijna, narodowościowa i polityczna spowodowała, że w wyniku historycznego rozwoju, utrwalania się tradycji i ewolucji praktyk społecznych każda wspólnota wykształciła swój własny, partykularny zakres pojęcia czym jest wolność słowa i jakie są jej granice. Mnogość znaczeń pojęcia wolności słowa jest zatem wynikiem relatywizmu kulturowego $^{72}$. Oczywiście modele wolności mogą być do siebie zbliżone, tak jak różnorodne wspólnoty oddziałują na siebie i przenikają się wzajemnie. Pomimo różnic kulturowych dzielących przykładowo Polaka od Francuza, obaj nadal są przedstawicielami cywilizacji Zachodu, a przez to wspólnie wyznają te same podstawowe wartości, o czym pisał dokładnie Samuel Huntington, charakteryzując cywilizację Zachodu ${ }^{73}$. Z całą jednak pewnością pojęcie wolności słowa nie będzie dla nich obydwu identyczne, ponieważ są przedstawicielami dwóch różnych narodowości.

70 T. Buksiński, op. cit., s. 85.

71 R. Prostak, Rzecz ..., s. 162.

72 W. Kymlicka, Wspótczesna ..., s. 263.

${ }^{73}$ Samuel Huntington wśród wspólnych cech charakteryzujących cywilizację Zachodu wymienił: po pierwsze, dziedzictwo starożytności klasycznej silniejsze niż w islamie i prawosławiu (na którą składa się: filozofia grecka, prawo rzymskie, język łaciński oraz religia chrześcijańska); po drugie, katolicyzm i protestantyzm (włącznie ze zjawiskami reformacji i kontrreformacji); po trzecie: mnogością języków europejskich; po czwarte, rozdział władzy świeckiej od duchownej, co przyczyniło się do wyjątkowego rozwoju idei wolności; po piąte, rządy prawa będące spuścizną porządku prawnego starożytnego Rzymu, średniowiecznej koncepcji prawa natury oraz anglosaskiej tradycji common law, mające zasadniczy wpływ na powstanie nowożytnego konstytucjonalizmu ze szczególnym podkreśleniem ochrony praw człowieka; po szóste, pluralizm społeczny, wyrażający się w powstaniu różnorodnych grup opartych nie na biologicznym pochodzeniu, ale na zgodzie do przynależenia do danej wspólnoty (np.: zakony, cechy, stowarzyszenia); po siódme, gremia przedstawicielskie, które będąc rozwinięciem pluralizmu społecznego zapewniły możliwość reprezentacji interesów arystokracji, duchowieństwa czy mieszczaństwa dały podwaliny pod nowożytne ustroje demokratyczne oraz tworzące nieznane w pozostałych cywilizacjach autonomie lokalne uzupełniające władzę przedstawicielska na szczeblu całego państwa; po ósme, indywidualizm, który jest podstawą tradycji praw i wolności jednostki, będący przeciwieństwem dominującego w pozostałych cywilizacjach kolektywizmu; S. Huntington, Zderzenie cywilizacji, Warszawa 2004, s. 100-104; O. Górecki, Ideologia wielokulturowości w geopolitycznej perspektywie konfliktu cywilizacji, [w:] P. Fiktus, H. Malewski, M. Marszał (red.), Wrocław 2015, s. 501-502. 
Podsumowując należy zauważyć, że wolność słowa, która podlega prawnej ochronie gwarantowanej przez państwo, nie jest dla komunitarian jedynie formalną i instytucjonalną regulacją określającą dopuszczalne zachowanie obywateli, lecz stanowi wewnętrzną składową dóbr etycznych charakterystycznych dla określonej wspólnoty, które państwo ma wcielać w życie ${ }^{74}$. Wynika z tego, że prawo publiczne nie może być neutralne wobec wartości wspólnotowych. Zdaniem komunitarian wolność słowa pozwala obywatelom na uczestnictwo w „namyśle publicznym” (zwanym również „deliberacją”), stanowiącym nic innego, jak wspólnotowy dyskurs moralny pozwalający na wypracowanie konsensusu i kompromisu w publicznej debacie ${ }^{75}$.

\section{BIBLIOGRAFIA}

Abbey R., Charles Taylor, Princeton 2000.

Abramson J., Bussiere E., Wolność stowa i prawo do swobodnego przekazu. Perspektywa Komunitariańska [w:] Komunitarianie. Wybór tekstów, red. P. Śpiewak, Warszawa 2004.

Bell D., Communitarianism and its Critics, Oxford 1993.

Breslin B., Communitarian Constitution, Baltimore 2004.

Buksiński T., Współczesne filozofie polityki, Poznań 2006.

Chmielwski A., Wprowadzenie. Filozofia moralności Alasdaira MacIntyre'a, [w:] A. MacIntyre, Dziedzictwo cnoty. Studium z teorii moralności, Warszawa 1996.

Chmielewski A., MacIntyre a wspótczesna filozofia polityczna, [w:] A. MacIntyre, Dziedzictwo cnoty. Studium z teorii moralności, Warszawa 2007.

Czarnecki S., Czy liberalizm deprecjonuje wspólnotę?, [w:] Indywidualizm, wspólnotowość, polityka, red. M.N. Jakubowski, A. Szahaj, K. Arbiszewski, Toruń 2002.

Dominiak Ł., Wartość wspólnoty. O filozofii politycznej komunitaryzmu, Torun 2010.

Drałus D., Charles Taylor. Sprzeczności pomiędzy filozofia a praktyka polityczna, [w:] Indywidualizm, wspólnotowość, polityka, red. M.N. Jakubowski, A. Szahaj, K. Arbiszewski, Toruń 2002.

Etzioni A., Wspólnota responsywna: perspektywa komunitariańska, [w:] Komunitarianie. Wybór tekstów, red. P. Śpiewak, Warszawa 2004.

Etzioni A., The New Golden Rule: Community and Morality in a Democratic Society, New York 1996.

Frazer E., the Problems of Communitarian Politics. Unity and Conflict, Oxford 2006.

Frost R., Contexts of Justice. Political Philosophy beyond Liberalism and Communitarianism, Los Angeles 2002.

Gawkowska A., Biorąc wspólnotę poważnie?, Warszawa 2004.

\footnotetext{
74 T. Buksiński, op. cit., s. 86.

75 A. Szahaj, Jednostka ..., s. 182-183.
} 
Gawkowska A., Jak rozwiewać obawy liberatów? O nie(dość) wykorzystanych zasobach teorii wspólnotowych, [w:] Teorie wspólnotowe a praktyka spoteczna. Obywatelskość, polityka, lokalność, red. A. Gawkowska, P. Gliński, A. Kościański, Warszawa 2005.

Gawkowska A., Komunitariańska krytyka kontraktualizmu, [w:] Umowa społeczna i jej krytycy w myśli politycznej i prawnej, red. Z. Rau, M. Chmieliński, Warszawa 2010.

Gawkowska A., Samorzad zobowiązanych obywateli (Michaela J. Sandela tęsknota za republikanizmem, [w:] Indywidualizm, wspólnotowość, polityka, red. M.N. Jakubowski, A. Szahaj, K. Arbiszewski, Toruń 2002.

Górecki O., Ideologia wielokulturowości w geopolitycznej perspektywie konfliktu cywilizacji, [w:] red. P. Fiktus, H. Malewski, M. Marszał, Wrocław 2015.

Grygieńć J., W trosce o wspólnotę i demokrację. Henry Tam i komunitarystyczny projekt polityczny, [w:] H. Tam, Komunitarianizm. Nowy program polityczny i obywatelski, Toruń 2011.

Huntington S., Zderzenie cywilizacji, Warszawa 2008.

Karnowska D., Spór o wspólnoty. Idee komunitarystyczne we współczesnej polskiej myśli politycznej, Toruń 2011.

Król M., Filozofia polityczna, Kraków 2008.

Krzyżaniak S., Jednostka, wspólnota, społeczeństwo. Dyskusje wobec współczesnego uporząlkowania społecznego, Zielona Góra 2003.

Kymlicka W., Wspótczesna filozofia polityczna, Warszawa 2009.

Kymlicka W., Liberalism, Community and Culture, Oxford 1991.

MacIntyre A., Czyja sprawiedliwość Jaka racjonalność?, Warszawa 2007.

MacIntyre A., Dziedzictwo cnoty. Studium z teorii moralności, Warszawa 1996.

MacIntyre A., Etyka i polityka, Warszawa 2009.

MacIntyre A., I'm not a Comunitarian, but..., „The Responsive Community”, 1999 (Summer), t. I, nr 3.

Mulhal S., Articulating the Horizons of Liberalism: Taylor's Political Philosophy, [w:] Charles Taylor, red. R. Abbey, Cambidge 2004, s. 114.

Philips D.L., Looking Backward. A Critical Appraisal of Communitarian Thought, Princeton 1993.

Prostak R., Liberalna autonomia, komunitarystyczna heteronomia. Charles Taylor jako krytyk teorii Sprawiedliwości Johna Rawlsa, [w:] Aktualność wolności. Wybór tekstów, red. P. Śpiewak, Warszawa 2005.

Prostak R., Rzecz o sprawiedliwości. Komunitarystyczna krytyka współczesnego liberalizmu amerykańskiego, Kraków 2004.

Rau Z., Liberalizm. Zarys myśli politycznej XIX i XX wieku, Warszawa 2000.

Redhead M., Charles Taylor. Thinking and Living Deep Diversity, Boston 2002.

Sandel M.J., Liberalizm a granice sprawiedliwości, Warszawa 2009.

Śpiewak P., Poszukiwanie wspólnot, [w:] Komunitarianie. Wybór tekstów, red. P. Śpiewak, Warszawa 2004.

Szahaj A., Jednostka czy wspólnota? Spór liberałów z komunitarystami a „sprawa polska”, Warszawa 2000. 
Szahaj A., Charles Taylor on Freedom, [w:] Charles Taylor's Vision of Modernity: Reconstructions and Interpretations, red. Ch. Grabowski, J. Hudzik, J. Kłos, Cambridge 2009.

Szahaj A., Jakubowski M. N., Filozofia polityki, Warszawa 2005.

Tam H., Komunitaryzm. Nowy program polityczny i obywatelski, Torun 2011.

Taylor Ch., Etyka autentyczności, Kraków 2002.

Taylor Ch., Nieporozumienia wokót debaty liberalno-komunitariańskiej, [w:] Komunitarianie. Wybór tekstów, red. P. Śpiewak, Warszawa 2004.

Tracz-Tryniecki M., Myśl polityczna i prawna Alexisa de Tocqueville, Kraków 2009.

Turowski M., Liberalizm po komunitaryzmie? Filozoficzne koncepcje jednostki, wspólnoty i państwa jako źródło krytyki społecznej i politycznej, Torun 2011.

Urbańczyk M., Liberalna doktryna wolności stowa a swoboda wypowiedzi historycznej, Poznań 2009.

Walzer M., O tolerancji, Warszawa 1999.

Walzer M., Sfery sprawiedliwości. Obrona pluralizmu i równości, Warszawa 2007.

Walzer M., Polityka i namiętność. O bardziej egalitarny liberalizm, Warszawa 2006.

Walzer M., Thick and Thin: Moral Argument at Home and Abroad, Notre Dame 1994.

Zdybel J., Między wolnościa a powinnościa. Filozofia polityczna Isaiaha Berlina i Alasdaira MacIntyre'a, Lublin 2005.

\section{FREEDOM OF SPEECH - COMMUNITARIAN ARGUMENTATION JUSTIFYING THE DIVERSITY OF THE MEANING OF THE TERM}

\section{Summary}

Communitarianism is one of the relatively new currents in contemporary political philosophy. Authors of this school of thought combine a relatively homogenous approach to tradition, culture, and society from the point of view of community values. The purpose of this article is to present the basic principles of communitarianism and attempt to reconstruct the meaning of "freedom of speech" on the basis of methodological assumptions of the analysed doctrine. For the purposes of the analysis, the differences between the representatives of communitarianism were excluded in order to concentrate on the most important and common methodological assumptions of communitarians. Among them are: critique of liberal individualism, the vision of individuals rooted in the community, and the vision of state. Communitarians consider freedom of speech, which is subject to legal protection guaranteed by the State, to not only be a formal and institutional regulation specifying the acceptable behaviour of citizens. It also represents an internal component of ethical goods specific to a particular community. Freedom of expression, understood in this manner, therefore allows citizens to participate in the "public thought" (also called "deliberation"), which con- 
stitutes the moral discourse of the community. It is aimed at developing a consensus and compromise in the public debate. From the point of view of freedom of speech, the philosophical and political doctrine of communitarians appears today to be particularly attractive. The reason behind this attractiveness is that they provide the theoretical arguments calling for the restoration of the forgotten community dimension in the life of citizens, the revitalization of a sense of social connection and the renewal of the approach to joint responsibility for the fate of fellow citizens.

\section{LA LIBERTÉ D'EXPRESSION - \\ L'ARGUMENTATION COMMUNAUTARIENNE JUSTIFIANT LA DIVERSITÉ DU SENS DE LA NOTION}

\section{Résumé}

Le communautarisme est l'un des courants relativement jeunes de la philosophie politique contemporaine. Les auteurs appartenant à ce courant sont unis pour proposer leur regard assez homogène sur la tradition, la culture et la société du point de vue de la communauté. Cet article vise à présenter les hypothèses de base du communautarisme et de tenter de faire la reconstruction de la signification du terme « liberté d'expression », en s'appuyant sur les hypothèses méthodologiques de la doctrine analysée.

Dans notre analyse, nous avons omis des différences entre les représentants du communautarisme, en faisant le point sur la présentation leurs hypothèses méthodologiques communs les plus importants, à savoir: la critique de l'individualisme libéral, la vision de l'homme enraciné dans sa communauté et la vision de l'État. Pour les communautariens, la liberté d'expression, qui est soumise à la protection juridique garantie par l'État, n'est pas une réglementation purement formelle et institutionnelle définissant un comportement acceptable des citoyens, mais elle est un composant interne des valeurs morales spécifiques pour une communauté particulière.

La liberté d'expression ainsi comprise permet aux citoyens de participer à « la délibération publique » qui constitue un discours moral communautaire dont le but est d'obtenir un consensus et un compromis lors d'un débat public. Aujourd'hui, du point de vue des questions relatives à la liberté d'expression, l'idée philosophique et politique présentée par les communautariens semble être extrêmement originale. En effet, elle fournit un argument théorique qui vise à restituer le sens communautaire oubliés de la vie des citoyens, à renouveler des liens sociaux ainsi que la responsabilité solidaire pour le sort des concitoyens. 